ELORE (ISSN 1456-3010), vol. 18 - 1/2011.

Julkaisija: Suomen Kansantietouden Tutkijain Seura ry. [http://www.elore.fi/arkisto/1_11/ajank_stranden.pdf]

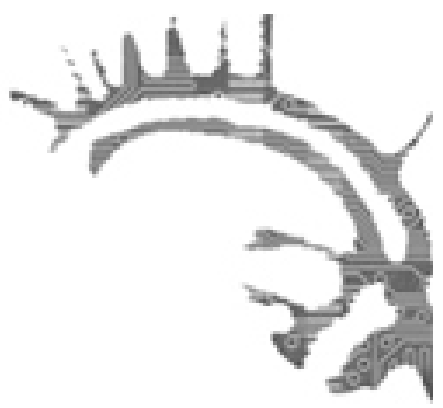

\title{
AKTUELL
}

\section{TYPFIGURER I DET MYTOLOGISERANDE BERÄTTANDET OM KRIGET I FINLAND}

Lectio praecursoria vid Abo Akademi 3.12.2010

\section{$\underline{\text { Sofie Strandén }}$}

Min forskning kretsar kring folkligt berättande om historia, folkligt berättande om krig. Min avhandling baserar sig på ett material som består av djupintervjuer med tio män och tio kvinnor som varit aktiva under vinterkriget och fortsättningskriget som soldater, förmän, fältpräst, lottor och sjuksköterskor. Jag inledde mitt fältarbete under 2003 med avsikten att intervjua män i olika ålder om deras förhållande till Johan Ludvig Runebergs diktverk Fänrik Ståls sägner. Detta gjordes på uppdrag av Svenska litteratursällskapet inför det kommande jubileumsåret 2004 då det var 200 år sedan nationalskalden föddes.

Huvudtiteln för min avhandling "I eld, $i$ blod, i frost, $i$ svält" har jag lånat från dikten "Soldatgossen" i nämnda verk. Fänrik Ståls sägner handlar om det krig som under åren 1808-1809 fördes mellan Sverige och Ryssland, och som ledde till att Sverige förlorade rikshalvan Finland till det ryska tsarväldet. Det nationalromantiska diktverket som utgavs i två delar 1848 och 1860 hade en enorm genomslagskraft och lästes flitigt i skolorna ända fram till krigsåren. Det är ändå inte berättande om diktverket min avhandling handlar om, eftersom de män som jag intervjuade och som själva hade varit med i kriget 1939-1944 pratade så mycket om sina egna krigsupplevelser och krigserfarenheter i stället för om Fänrik Stål. Mitt material handlar alltså om personligt berättande om krig. 


\section{Sofie Strandén: Typfigurer i det mytologiserande berättandet om kriget i Finland}

I min forskning om berättande om krig har jag funnit underlag för ett figurtänkande som bygger på ett antagande om berättande som socialt konstruerat. Jag vill här i mitt anförande lyfta fram särskilt en av dessa figurkonstruktioner, som jag har valt att kalla för typfigur.

Jag ser en typfigur som ett starkt symboliskt laddat uttryck som i förtätad form uttrycker värderingar, åsikter och moraluppfattningar. Jag inleder med några exempel på typfigurer som jag diskuterar i min avhandling, för att därefter sätta mitt begrepp i relation till andra liknande konstruktioner. Slutligen gör jag en kort analys av typfigurer i det mytologiserande berättandet om kriget i Finland som en utveckling av det jag har skrivit om.

\section{TYPFIGURER}

De typfigurer som förekommer i mitt material framställs oftast mer eller mindre entydigt positivt eller negativt, idealiserande, förlöjligande, fördömande eller demoniserande. Jag har hittat typfigurer som exempelvis Den ståndaktige soldaten, Florence Nightingale-sjuksköterskan, Den elaka styvsystern, Den djuriske ryssen, Fosterlandsförsvararen och Kommunisten. Dessa typfigurer används av intervjupersonerna som ett direkt sätt att tradera innehållslig kunskap om kriget. Samtidigt genererar också typfigurerna i mitt material indirekt vissa särskilda moraluppfattningar som hör hemma inom en viss ideologi som man kunde kalla kristen-fosterländsk. Genom att man berättar om sina upplevelser från kriget med hjälp av de symboliskt starkt laddade typfigurerna kommunicerar man något utöver det direkt utsagda. Detta något ser jag som folklig moral, det vill säga folkliga uppfattningar om rätt och orätt beteende och förhållning till världen runtomkring.

Typfigurerna förekommer på ett delvis annat plan än den vardag vi lever i. Man kan hänföra dem till ett mytiskt universum där de lever ett episkt liv som inte begränsas av vår tids- och rumsuppfattning. Typfigurer uppstår med de människor som omtalas som grund, som ett slags renodling av de människor som man mött, sett, hört talas om, levt och arbetat med eller som en sådan människa man identifierar sig och framställer sig själv som. Upptäckten av ett sådant fenomen är inte ny. Exempelvis oral history-forskarna Raphael Samuel och Paul Thompson identifierar den här formen av aktörer i berättandet som något som hör folkloren till trots att aktörerna i fråga tar skepnad av verkliga och namngivna människor. Ekonomen Markus Kallifatides är likaledes inne på samma fenomen när han beskriver olika slag av ledarfigurer som kännetecknas av en viss typ av praktik och som han anser finns i de stora berättelsernas tid. Fenomenet i sig är alltså uppmärksammat, men begreppet typfigur är dock nytt och myntat av mig. Man kan se typfigurer som ett slags roller som förtydligar de handlande aktörerna och de människor som omtalas i berättandet.

Typfigurer får stå som konkretiserade uttryck som på ett symboliskt plan kan visa värderingar och åsikter. Typfigurer är liksom stereotyper en förenkling. En stereotyp förklaras i uppslagsverket Nationalencyklopedin som en allmänt omfattad föreställning om utmärkande egenskaper hos alla som tillhör en viss grupp, ofta också med kraftigt negativ konnotation. En stereotyp handlar om en föreställning om något medan en 
typfigur blir ett konkret uttryck. Typfigurer kan uttrycka en stereotyp, och man kan i vissa fall se att typfigurer är en personifiering av en stereotyp. En typfigur kan genom sin tydliga gestaltning sägas uttrycka den samlade effekten av åsikter, värderingar och handlingar som framträder i berättande. En typfigur kan ge uttryck för negativt laddade värderingar om andra, men likaväl också en stark idealisering av ett eller annat slag.

Carl Gustaf Jungs begrepp arketyp kommer också i närheten av en typfigur, utan att ändå låta sig förväxlas. En arketyp representerar universella föreställningar i det Jung kallade för det kollektiva omedvetna, och brukar exemplifieras som modern, draken eller hjälten. En typfigur kan uttrycka en arketypisk föreställning, men gör detta i så fall i mera konkret form och utan att anta fullt så mytiska proportioner som Jungs arketyper. Man kan också se typfigurer som en mera vardaglig och jordnära form av de mytiska arketyperna. Ett exempel på en sådan ur mitt material kunde vara typfiguren Florence Nightingale-sjuksköterskan som har en del gemensamma drag med arketypen modern.

Man kan säga att typfigurer är i tjänst hos det mytologiserande berättandet, och jag föreställer mig att det är så oberoende av vad berättandet handlar om. Typfigurer är markörer för att ett berättande är mytologiserande eftersom de visar på normer, ideal och moral - människors sätt att tänka. De, liksom andra formaliserade folkloreuttryck som exempelvis ordspråk, är markörer för vad som anses vara viktigt och rätt i ett samhälle. Tack vare sin förtätade form är de lätta att kommunicera och förstås i en given kontext, och sålunda är de ett effektivt redskap att förmedla värderingar.

\section{MORALUPPFATTNINGAR OCH SYMBOLISKA LADDNINGAR}

En moraluppfattning som kan skönjas i berättandet om kriget är värnet av hemmet. Alla lidanden och försakelser under kriget görs meningsfulla genom hemmet - allt det svåra man genomled gjorde man för att skydda hemmet. Devisen att kämpa för tro, hem och fosterland användes av marskalk Carl Gustaf Mannerheim i flera av hans dagorder under kriget som en symbol för allt det som ansågs heligt och dyrbart. Uttrycket finns också med i det löfte som lottorna avgav när de i kyrkan svor lottaeden. Uttrycket innefattar religionen, ideologin och hem, hembygd och familj. Här kan man dessutom se hemmet på flera nivåer: fosterlandet som det stora hemmet, hembygden med släkten och traditionerna, och det lilla hemmet som är det egna fysiska hemmet med familjen. Typfigurer från mitt material som kan exemplifiera detta är Den ståndaktige soldaten, Den dygdiga lottan och Fosterlandsförsvararen.

Det mytologiserande berättandet om krig har en stark symbolisk laddning. Den norska folkloristen Anne Eriksen studerar det hon kallar för den nationella grundberättelsen i Norge, och hon visar hur man genom den tar fram hur det lilla och underlägsna landet Norge står enat under andra världskriget mot en yttre fiende - den tyska ockupationsmakten - som är till synes helt överlägsen. En liknande nationell grundberättelse finns också i Finland. Liksom den norska handlar den finländska om det lilla landet som utstår stort lidande under kriget, men som tack vare att alla invånare enhälligt kämpar tillsammans mot den övermäktiga fienden klarar sig med äran i behåll ur den svåra situationen. Denna grundberättelse har ett mönster som känns 
igen från Bibelns berättelse om David och Goliat, och kan exemplifieras med den så kallade vinterkrigsandan. Finland, som efter inbördeskriget 1918 var djupt splittrat, "enades och förenades i en kamp för ett gemensamt mål. De motsättningar som fanns i samhället täcks över av berättandet som visar upp en bild av ett enat förflutet där alla var sams och som, med vissa undantag som fördöms, gjorde allt för att försvara fosterlandet. I spänningen här finner man också berättande som inte passar in i det mytologiserande berättandet, och som ger indikationer för hur tvingande och stark mytologiseringen är med avseende på vad som kan och får berättas.

I mytologiserande berättande finns det högre värden som inte kan ifrågasättas eller emotsägas. Sådana värden kan vara försvaret av tro, hem och fosterland. Eftersom dessa värden inom den kristen-fosterländska ideologin är så dyrbara måste de inplanteras i kommande släktled, vilket intervjupersonerna gör genom att med sitt berättande undervisa mig som en representant för en yngre generation som inte själv var med under kriget. Typfigurer som kan användas för att förklara vikten av att försvara sådana värden är Fosterlandsförsvararen, Den djuriske ryssen, Kommunisten, Nazisten och Den fege svikaren. De ovan nämnda typfigurerna förmedlar endera en förebild för hur man borde agera, utgör avskräckande exempel för hur man inte ska tänka och handla, samt förtydligar ett tänkande om vi och de andra som förklarar ett inkluderande vi som något väsenskilt från ett de andra. Det mytologiserande berättandet om kriget i Finland visar på det lilla landet som så orättfärdigt angreps av den stora grannen, och som enigt, envist och segt kämpade mot fienden som hotade den kristen-fosterländska ordningen.

\section{MYTOLOGISERANDE BERÄTTANDE}

Jag vill i det följande skissera upp centrala typfigurer som visar på det mytologiserande berättande om kriget och landet Finland, för att kunna visa på den starka inneboende drivkraften i det mytologiserande berättandet. I centrum står typfiguren Veteranen, den åldrade versionen av typfiguren Fosterlandsförsvararen som återfinns i mitt material i många olika tappningar. Han, för Veteranen framställs alltid som en man, har flera hjälpare i bakgrunden. En av de viktigaste beståndsdelarna är den kristenfosterländska ideologin som han som barn anammade i skolan genom exempelvis Fänrik Ståls sägner.

Rent konkret står de fosterländskt sinnade kvinnorna vid såväl Fosterlandsförsvararens som Veteranens sida i form av typfiguren Den dygdiga Lottan. Lottan har blivit symbol för kvinnor i Finlands krig oberoende av om kvinnorna de facto hörde till organisationen Lotta Svärd eller till någon annan. Namnet Lotta Svärd härrör i sig från dikten om Lotta Svärd i Fänrik Ståls sägner, en figur som mest har sitt starka fosterlandspatos gemensamt med lottaorganisationens kvinnor. Diktens Lotta hade som uppgift att sälja brännvin till soldaterna. Det är alltså fosterländskheten som förenar kvinnorna som är lottor med diktverkets Lotta, inte deras uppgifter. Det är också fosterländskheten som blir en drivkraft för både viljan att dra ut i krig och viljan att berätta om upplevelserna efteråt.

Som jag visade nyss slåss Fosterlandsförsvararen mot motståndare av olika slag 


\section{Sofie Strandén: Typfigurer i det mytologiserande berättandet om kriget i Finland}

personifierade som Den djuriske ryssen, Kommunisten och Den fege svikaren. Den överväldigande fienden kan ses som en personifiering av Bibelns Goliat, Kommunisten är den som i en fosterländsk kontext försöker bistå fienden i hans strävanden att omintetgöra Finland. De som flydde undan striderna fördöms eftersom de inte försökte försvara det som ansågs vara dyrbart. Veteranen, den åldrande Fosterlandsförvararen som vi möter i dag, är den som ska kämpa mot en okunskap som tillskrivs yngre generationer som inte själva deltagit i kriget. Här kan man se startpunkten för något som kan liknas vid en missionsbefallning: Veteranen som i sig är en personifiering av högstående fosterländsk moral ska berätta om fosterlandets lidanden och vedermödor i kampen för Det fria landet Finland som så oförskyllt anfölls av den stora grannen i öster. Veteranen blir en apostel som ska sprida det rätta ideologiska budskapet vidare till nya generationer, till dem som är arvtagare till Det fria landet Finland.

Kvinnorna kan ses som ett slags lärjungar, men som tystare eller tystade sådana, eftersom deras roll är stödjande. Liksom en av Bibelns Marior sitter passivt lyssnande vid Jesu fötter, ska också kvinnorna som var med i kriget hitta sin plats lite bredvid och nedanom männen och själva inte prata om sina erfarenheter. Berättandet överlåts till männen. Om kvinnorna däremot likt Bibelns Martha, syster till den lyssnande Maria, tar sig en aktiv roll, även om handlingarna liksom Marthas också kretsar kring sådant som arketypiskt moderligt ansetts lämpligt för kvinnor, det vill säga matlagning och vård av sjuka och skadade, kan de näpsas för sin aktivitet som när Jesus klandrade Martha för hennes vardagliga bestyr i köket när han, Mästaren var på besök. Den aktiva kvinnan hör inte hemma i mytologiserande berättande om krig, i själva verket hör kvinnan inte över huvud taget hemma i en krigskontext. Därför blir hennes blotta närvaro, faktiska och aktiva existens där tillräcklig för att allmänheten ska göra henne liktydig med typfiguren Horan, vilket i sig är ett effektivt redskap för nedtystning. Kvinnan passar stereotypt inte in i krig.

En av motståndarna till Veteranen som jag visade på ovan är de som flydde undan striderna och som jag valt att omtala som Den fege svikaren. Här handlar det om någon som av en eller annan anledning inte alls accepterar den kristen-fosterländska ideologin eller som inte gör det i tillräckligt hög grad för att vilja riskera livet för de värden som hör till. I en jämförelse med Bibeln kan man se typfiguren Den fege svikaren som en Judas-gestalt. Alternativt kan denna typfigur beskrivas som sådana personer som förnekade sin kristna tro för att inte behöva lida martyrdöden. Mönstret att man anses svika de värderingar som ses som goda är de samma, och leder till samma fördömande. Denna typfigur passar inte in i det mytologiserande berättandet om kriget. Samtidigt behövs den för att visa på de uppoffringar som de fosterlandsfrälsta gjorde, och ju nesligare Den fege svikaren görs, desto mer glorifierad blir Fosterlandsförsvararen.

Jag har som sagt utgått från intervjupersoners berättande om krig, men forskningen kunde vidgas utgående från tankegångarna om typfigurer och mytologisering med studier av Mannerheim som typfiguren Den gudomliggjorde krigarkungen och därmed mytologiseringen av honom, med forskning om mytologisering av krig mer allmänt i populärkulturen i form av krigsskildringar på film och i TV-serier, granskning av 
Sofie Strandén: Typfigurer i det mytologiserande berättandet om kriget i Finland

relationen mellan Runebergs diktfigurer och personers självbiografiska krigsberättande i populärhistoriska verk eller genom ett närmande av firandet av märkes- och helgdagar som internationella veterandagen, de stupades dag och självständighetsdagen som symboler i en nationell mytologiserande berättelse.

Strandén, Sofie 2010: "I eld, i blod, i frost, $i$ svält". Möten med veteraners, lottors och sjuksköterskors berättande om krig. Digital avhandling i ämnet folkloristik vid Åbo Akademi.

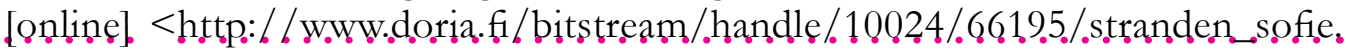
pdf?şequencence=1>>

Filosofie doktor Sofie Strandén forskar inom Svenska litteratursällskapets projekt "Bitar av samma pussel? Intersektionella perspektiv på det svenska i Finland". 